not only with the fully adult animal, but also with the African species, because of the striking and singular differences displayed by the two species in the matter of what one might almost call the 'armourplating' formed by the hide. No one has yet been able to find any explanation for the fact that in the Indian species this forms what looks like a series of separate shields, or 'bucklers', studded with relatively small round bosses, while in the African species the hide forms a continuous covering. Again, we seek in vain for any intelligible explanation of the fact that while the African species has two nasal horns, in the Indian and other Asiatic rhinoceroses there is but one horn. There are, of course, other structural differences between these two types, which, some day, may be compared with all the known fossil remains. When this has been done, we may well find clues such as will help us to gain an insight as to the factors and mode of evolution of these singularly interesting ungulates.

\section{The Old Ashmolean, Oxford}

THE two hundred and fiftieth anniversary of the opening of the Old Ashmolean, Oxford, falls on May 21, a date duly recorded by Elias Ashmole, donor of its original possessions. In recognition of this occasion, Dr. R. T. Gunther, curator of the Lewis Evans Collection of Scientific Instruments, housed in the Old Ashmolean, has been able to conclude a series of arrangements to mark the event. Here it may be mentioned that the Old Ashmolean building itself was erected between 1679 and 1683 , and is attributed, on fairly good grounds, to Christopher Wren. The appropriateness of this historic establishment for the housing of the Lewis Evans collection of ancient scientific instruments was demonstrated in 1925, when this notable gift to Oxford was dedicated by the Earl of Crawford and Balcarres at a special meeting held in the Old Ashmolean, and the collection was declared open. The principal celebration arrangements referred to above comprise a reception by the curator of the Lewis Evans Collection, on Sunday, May 21, whilst on May 22, at 2.30 p.m., in the University Museum, Sir Arthur Smith Woodward will deliver a lecture on "Plot and Lhwyd and the Dawn of Geology". These naturalists were the first keepers of the Old Ashmolean. During the week, exhibitions of Ashmolean interest will be open to the public, including portraits and relics, books, manuscripts, and engravings.

\section{Centenary of the University of Zurich}

The centenary celebrations of the University of Zurich, which extended from April 28 until May 1, attracted a large number of delegates from the universities and learned societies of the world. At the chief ceremony, held in the noble 'Lichthof' of the University on April 29, the addresses of the Rector (Prof. F. Fleiner) and the director of education of Canton Zurich (Dr. O. Wettstein) were followed by congratulatory speeches by selected representatives of the various nations. The delegates from the British Isles were Prof. A. E. Zimmern (Oxford),
Prof. G. H. F. Nuttall (Cambridge), Dr. T. Loveday (Bristol), Sir Henry Miers (Royal Society), Prof. J. Read (St. Andrews), Prof. E. Dieth (Aberdeen), Prof. J. H. S. Burleigh (Edinburgh), and Prof. F. E. Hackett (Dublin). At its foundation, the teaching staff of the University comprised twenty-three professors, thirty-three lecturers, and 161 students; at the present day, it has about a hundred professors, ninety lecturers, and some 2,000 matriculated students. In 1908, the University took a great step forward as a result of a referendum in which the people of Canton Zurich voted in favour of the provision of extensive new accommodation: "durch den Willen des Volkes", runs the inscription carved in stone over the western entrance to the magnificent central building which was erected at that time. The city of Zurich was en fête during the celebrations, and the popular interest and pride in the cantonal university were pleasingly evident on every hand. "Akademische Lehr- und Lernfreiheit ist an ihr geltend", is a significant sentence occurring in the original statutes of the University, and the adherence of the University, the canton, and the Swiss nation to the cherished ideals of freedom and toleration formed the keynote of most of the speeches at the celebrations.

\section{Huxley and Scientific Education}

HUXIEY memorial lectures have been delivered at the Imperial College of Science and Technology, London, annually since 1925 to commemorate the life and work of Thomas Henry Huxley, who was born on May 4, 1825, was professor of biology from 1854, and dean of the Royal College (then Normal School) of Science and Royal School of Mines from 1881 until his death in 1895. The lecture this year was delivered by Prof. H. E. Armstrong, who, as a pupil of Huxley's, and as professor of chemistry at the Central Technical College, and equally concerned with the outlook and methods of education, was able to garnish his tribute with personal reminiscence and with forceful criticism of the scientific world as it appears to him to-day. Huxley's reputation as a master of education rests, he said, mainly upon his writings and public addresses, not upon his work as a teacher. "He was a marvellous exponent-therefore, a bad teacher, as are all who are eloquent" ; "a master of fine logic, but encased in hard bones". Prof. Armstrong attended some of Huxley's lectures, but they failed to hold the interest of one who hoped to learn how things had been found out; neverthe. less, he ever regretted that he did not attend the Working Men's Lectures, in which Huxley told a consecutive story.

Prof. Armstrong said he knew no book from which more general inspiration is to be derived than from the third volume of Huxley's essays, "Science and Education", though it was published in 1895 and goes back to 1854 ; yet there is little in the essays bearing on actual teaching. Huxley was insistent on the need for organisation. "In the sense in which he meant it, we remain unorganised to-day, whilst the need is much greater. Many may think that his 